\section{Divergent Transplant Production Practices Produce Comparable Growth, Yield, and Quality of Processing Tomatoes}

\author{
T.K. Hartz, C. Giannini, E.M. Miyao ${ }^{1}$, and J.G. Valencia ${ }^{1}$ \\ Department of Vegetable Crops, University of California, Davis, CA 95616
}

Additional index words. mineral nutrition, Lycopersicon esculentum

\begin{abstract}
The effect of transplant production and handling practices on processing tomato growth, yield, and fruit quality were evaluated in five field trials in California. In 1999, processing tomato (Lycopersicon esculentum Mill. cv. Halley) transplants were obtained from a number of commercial transplant producers and taken to the Univ. of CaliforniaDavis (UCD) where treatments were imposed for 1 week prior to transplanting. Treatments included $\mathbf{N}$ and $\mathbf{P}$ fertilization, exposure to lath house or greenhouse temperature, withholding water, and storage in the dark for 2 days to simulate shipment from greenhouse to field. Nine treatments per site were compared in field trials at Yolo, Woodland, and Knights Landing. In 2000, transplants were grown at UCD under varying nutrient regimes, including $P$ fertilization rates ranging from weekly application of 0 to 90 $\mathrm{mg} \cdot \mathrm{L}^{-1}$. Two commercial field trials comparing 8 treatments were conducted near Winters and Newman. Although transplant production and handling practices significantly influenced relative growth rate in the 3-4 weeks following transplanting in all 1999 trials, effects on fruit yield were minimal, with only one treatment at Woodland showing significantly lower yield and no treatment differences in crop maturity, fruit soluble solids, or juice color observed at any site. In 2000, plants receiving no weekly $P$ fertilization showed slower growth in the 3 weeks after transplanting, but no treatment differences were observed after 6 weeks. Fruit yield, soluble solids content $\left({ }^{\circ}\right.$ Brix) and juice color were unaffected by transplant treatment. We conclude that transplant production and handling practices tested had minimal differential effect on the subsequent field performance of processing tomato transplants in the Central Valley of California.
\end{abstract}

Production practices for tomato transplants have been studied by numerous researchers; issues investigated have included macronutrient nutrition (Ciardi et al., 1998; Garton and Widders, 1990; Masson et al., 1991; Melton and Dufault, 1991; Vavrina et al., 1998; Weston and Zandstra, 1986; Widders, 1989), root cell size (Kemble et al., 1994; Marr and Jirak, 1990; Weston and Zandstra, 1986), transplant age (Leskovar et al., 1991; Weston and Zandstra, 1989) and hardening practices (Ciardi et al., 1998; Leskovar and Cantliffe, 1991; Melton and Dufault, 1991). Results have frequently been contradictory. Weston and Zandstra (1989), Masson et al.. (1991), and Melton and Dufault (1991) all reported that N fertigation at $200-400 \mathrm{mg} \cdot \mathrm{L}^{-1}$ was superior to lower rates, while Garton and Widders (1990) found $75 \mathrm{mg} \cdot \mathrm{L}^{-1} \mathrm{~N}$ to be optimal, and Vavrina et al. (1998) reported rates as low as $15 \mathrm{mg} \cdot \mathrm{L}^{-1}$ $\mathrm{N}$ to be adequate under some circumstances. Leskovar et al. (1991) reported that transplants as young as 2 weeks may perform satisfactorily, while Weston and Zandstra (1989) found maximum yields with 5-6-weekold transplants. Ciardi et al. (1998) found that pretransplant chilling aided in field establishment, but Melton and Dufault (1991) reported no positive effects of chilling. These varying results suggest that site-specific factors in both

Received for publication 4 Dec. 2000. Accepted for publication 25 May 2001.

${ }^{1}$ Univ. of California Farm Advisors in Yolo/Solano and Stanislaus Counties, respectively. the greenhouse and field may confound treatment effects, making generalization about appropriate tomato transplant production and handling practices difficult.

The widespread use of transplants in the California processing tomato industry is a recent development. Until the early 1990s nearly all fields were established by direct seeding; currently at least 30,000 ha are transplanted annually. California tomato transplant producers vary widely in production practices. No relevant research exists to guide these transplant producers, or to allow field growers to evaluate quality of the transplants they purchase. This study was undertaken to assess the effects of a range of transplant production and handling practices on the field establishment, productivity and fruit quality of processing tomato under representative California conditions.

\section{Materials and Methods}

1999. Experiments were conducted in commercial processing tomato fields near Yolo, Woodland, and Knights Landing in central California. Transplanting dates were 7 and 14 Apr., and 3 May, respectively. Tomato transplants (cv. Halley) were obtained from various commercial transplant producers in California about a week prior to each transplant date; a different set of plants was obtained for each field trial. These plants were transported to the Univ. of California-Davis (UCD) where a range of hardening and handling practices were im- posed (Table 1). Those treatments included $\mathrm{N}$ and $\mathrm{P}$ fertilization, exposure to lath house (ambient) or greenhouse temperatures, withholding water, and storage in the dark for $2 \mathrm{~d}$ before transplanting to simulate shipment from greenhouse to field. The goal was to produce transplants representing a wide range of plant size and condition to compare in each field trial. From the combination of transplant source and final handling practices a total of eight treatments were developed for each field trial.

The field performance of these eight treatments, plus the transplants (also 'Halley') being planted by the cooperating field grower, was compared in a randomized complete-block design, with five replications per treatment. Individual plots were $30 \mathrm{~m}$ long $\times$ one $1.5-\mathrm{m}$ bed wide, and contained $\approx 100$ plants. The plants were mechanically transplanted, and a fertilizer solution containing $\mathrm{N}$ and $\mathrm{P}$ was applied at or prior to transplanting, either as a band near the plant row or as a drench with each plant. The $\mathrm{N}$ application rates were 15,6 , and $17 \mathrm{~kg} \cdot \mathrm{ha}^{-1}$, and $\mathrm{P}$ application rates were 15,9 , and $20 \mathrm{~kg} \cdot \mathrm{ha}^{-1}$ at Yolo, Woodland, and Knights Landing, respectively.

At transplanting, the following measurements were made on 45 representative plants per treatment per field: plant height, root cell volume, shoot dry mass, and shoot macronutrient concentration. Shoot N concentration was determined by the combustion method of Sweeney (1989), and K concentration by atomic emission spectrometry following extraction in $2 \%$ acetic acid. Shoot $\mathrm{P}$ was determined by inductively coupled plasma atomic emission spectrometry following microwave acid digestion (Sah and Miller, 1992).

Percent stand loss was determined about a week after transplanting. The shoots of 10 transplants per plot were collected either 4 (Yolo) or 3 weeks (Woodland and Knights Landing) after transplanting to evaluate rate of early growth. To account for differences among treatments in initial plant mass, relative growth rate was calculated by the method of Hunt (1990). The cooperating growers provided routine management throughout the season; all fields were furrow-irrigated after an initial sprinkler irrigation.

A single, destructive mechanical harvest was conducted in all fields when $\approx 95 \%$ of fruit had reached maturity. Harvest dates were 16 and 22 Aug. and 6 Sept. for Yolo, Woodland, and Knights Landing, respectively. Total fruit yield, percentage of green fruit, percentage of soluble solids [SS ( ${ }^{\circ}$ Brix $)$ ], and juice color [ratio of green $(566 \mathrm{~nm})$ to red $(650 \mathrm{~nm})$ light reflected from the juice] were determined.

2000. In 2000, all transplants (cv. Halley) were grown at UCD. The tray medium, a peat/ vermiculite blend, was augmented with 0.17 $\mathrm{kg} \cdot \mathrm{m}^{-3} \mathrm{P}$ (from bone meal). Four transplant treatments were imposed, representing one of the following P nutrition regimes: weekly application of $0,30,60$, or $90 \mathrm{mg} \cdot \mathrm{L}^{-1} \mathrm{P}$, applied in conjunction with a uniform application of $150 \mathrm{mg} \cdot \mathrm{L}^{-1} \mathrm{~N}$ and $\mathrm{K}$. Formulation of the nutrient solutions is given in Table 2. These treatments received a normal hardening exposure of at least a week in a lath house at ambient 
Table 1. Transplant source, finishing treatment applied, and transplant characteristics at planting, 1999 and 2000 trials.

\begin{tabular}{|c|c|c|c|c|c|c|c|c|}
\hline \multirow{2}{*}{$\begin{array}{l}\text { Treatment } \\
\text { no. }\end{array}$} & \multirow{2}{*}{$\begin{array}{c}\text { Greenhouse } \\
\text { source }^{z}\end{array}$} & \multirow{2}{*}{$\begin{array}{c}\text { Finishing } \\
\text { treatment applied }\end{array}$} & \multirow{2}{*}{$\begin{array}{c}\text { Root cell } \\
\text { volume }\left(\mathrm{cm}^{3}\right)\end{array}$} & \multirow{2}{*}{$\begin{array}{c}\text { Plant } \\
\text { dry wt (g) }\end{array}$} & \multirow{2}{*}{$\begin{array}{c}\text { Plant } \\
\text { height }(\mathrm{cm})\end{array}$} & \multicolumn{3}{|c|}{ Shoot concn $\left(\mathrm{g} \cdot \mathrm{kg}^{-1}\right)$} \\
\hline & & & & & & $\mathrm{N}$ & $\mathrm{P}$ & $\mathrm{K}$ \\
\hline \multicolumn{9}{|c|}{1999} \\
\hline \multicolumn{9}{|c|}{ Yolo } \\
\hline 1 & 1 & normal hardening & 16 & 0.21 & 20.4 & 21 & 5.1 & 52 \\
\hline 2 & 2 & normal hardening & 15 & 0.19 & 21.8 & 19 & 2.2 & 45 \\
\hline 3 & 3 & normal hardening & 17 & 0.20 & 19.5 & 17 & 2.1 & 37 \\
\hline 4 & 3 & fertilization with $10-22-0$ & 17 & 0.20 & 19.2 & 19 & 2.5 & 34 \\
\hline 5 & 2 & water stress, in lath house & 15 & 0.17 & 22.7 & 18 & 2.2 & 46 \\
\hline 6 & 1 & 2-d dark exposure & 16 & 0.19 & 21.7 & 22 & 5.7 & 57 \\
\hline 7 & 2 & 2-d dark exposure & 15 & 0.18 & 24.2 & 19 & 2.5 & 51 \\
\hline 8 & 1 & water stress, in greenhouse & 16 & 0.23 & 21.6 & 21 & 4.8 & 49 \\
\hline 9 & & field standard & 17 & 0.18 & 17.9 & 17 & 6.7 & 35 \\
\hline \multicolumn{9}{|c|}{ Woodland } \\
\hline 1 & 2 & normal hardening & 15 & 0.16 & 19.0 & 27 & 4.1 & 45 \\
\hline 2 & 2 & fertilization with $10-22-0$ & 15 & 0.16 & 19.4 & 28 & 4.6 & 47 \\
\hline 3 & 2 & water stress, in greenhouse & 15 & 0.15 & 21.0 & 32 & 4.6 & 51 \\
\hline 4 & 2 & 2-d dark exposure & 15 & 0.14 & 20.3 & 31 & 4.5 & 45 \\
\hline 5 & 4 & normal hardening & 24 & 0.24 & 23.3 & 25 & 2.1 & 47 \\
\hline 6 & 5 & normal hardening & 16 & 0.12 & 23.0 & 28 & 11.7 & 60 \\
\hline 7 & 4 & fertilization with $10-22-0$ & 24 & 0.25 & 23.3 & 27 & 3.1 & 48 \\
\hline 8 & 4 & lath house day, $10^{\circ} \mathrm{C}$ chamber at night & 24 & 0.22 & 24.3 & 31 & 2.8 & 51 \\
\hline 9 & & field standard & 17 & 0.14 & 19.9 & 25 & 2.5 & 48 \\
\hline \multicolumn{9}{|c|}{ Knights Landing } \\
\hline 1 & 2 & normal hardening & 15 & 0.29 & 16.7 & 16 & 1.9 & 37 \\
\hline 2 & 2 & 2-d dark exposure & 15 & 0.26 & 18.4 & 16 & 1.9 & 37 \\
\hline 3 & 2 & fertilization with $10-22-0$ & 15 & 0.22 & 21.5 & 17 & 2.7 & 37 \\
\hline 4 & 2 & fertilization with $20-9-17$ & 15 & 0.27 & 21.9 & 17 & 2.4 & 34 \\
\hline 5 & 4 & normal hardening & 24 & 0.39 & 25.9 & 28 & 1.3 & 42 \\
\hline 6 & 4 & 2-d dark exposure & 24 & 0.37 & 25.4 & 30 & 1.3 & 42 \\
\hline 7 & 6 & normal hardening & 16 & 0.18 & 22.6 & 29 & 11.0 & 41 \\
\hline 8 & 7 & normal hardening & 26 & 0.36 & 21.7 & 13 & 2.2 & 26 \\
\hline 9 & & field standard & 23 & 0.20 & 20.4 & 20 & 2.3 & 46 \\
\hline \multicolumn{9}{|c|}{2000} \\
\hline 1 & 7 & $0 \mathrm{P}$ & 26 & 0.20 & 17.8 & 43 & 2.2 & 38 \\
\hline 2 & 7 & $30 \mathrm{P}$ & 26 & 0.27 & 18.4 & 36 & 3.4 & 39 \\
\hline 3 & 7 & $60 \mathrm{P}$ & 26 & 0.24 & 22.2 & 42 & 6.1 & 39 \\
\hline 4 & 7 & $90 \mathrm{P}$ & 26 & 0.20 & 23.5 & 47 & 9.2 & 34 \\
\hline 5 & 7 & $\operatorname{trt} 3+10-22-0$ & 26 & 0.27 & 28.0 & 59 & 13.2 & 43 \\
\hline 6 & 7 & trt $3+$ water stress, in greenhouse & 26 & 0.25 & 24.1 & 38 & 5.9 & 32 \\
\hline 7 & 7 & trt $3+20-9-17$, in greenhouse & 26 & 0.37 & 24.1 & 53 & 11.5 & 47 \\
\hline 8 & 7 & trt $3+20-9-17$, in lath house & 26 & 0.28 & 15.2 & 59 & 12.0 & 40 \\
\hline
\end{tabular}

${ }^{2}$ Transplants grown by 7 commercial transplant operations throughout central California; production practices, tray media and cell volume differed yHandling practices employed during the week preceding transplanting in 1999; plants maintained in a lath house at UCD at ambient temperature unless otherwise stated. Normal hardening indicates no fertilizer and limited water applied; treatments employing fertilization applied twice. Treatments held in the greenhouse were maintained at $25^{\circ} \mathrm{C}$ day $/ 15^{\circ} \mathrm{C}$ night. In 2000 , treatments $1-4$ received weekly application of $150 \mathrm{mg} \cdot \mathrm{L}^{-1} \mathrm{~N}$ and $\mathrm{K}$, together with the $\mathrm{mg} \cdot \mathrm{L}^{-1}$ of P specified; treatments $5-8$ received all fertilizer applications of treatment 3 plus the additional treatment specified during the final 2 weeks before transplanting. In both years fertilization with either 10 $22-0$ or $20-9-17$ was at $400 \mathrm{mg} \cdot \mathrm{L}^{-1}$ of material.

Table 2. Composition of nutrient solutions applied weekly to tomato transplants in 2000 .

\begin{tabular}{lcccc}
\hline \hline \multirow{2}{*}{ Treatment } & \multicolumn{4}{c}{ Solution concn $\left(\mathrm{mg} \cdot \mathrm{L}^{-1}\right)$} \\
\cline { 2 - 5 } & $\mathrm{NH}_{4} \mathrm{H}_{2} \mathrm{PO}_{4}$ & $\mathrm{KH}_{2} \mathrm{PO}_{4}$ & $\mathrm{KNO}_{3}$ & $\mathrm{NH}_{4} \mathrm{NO}_{3}$ \\
\hline 1 & 0 & 0 & 385 & 274 \\
2 & 56 & 65 & 336 & 274 \\
3 & 112 & 130 & 287 & 274 \\
4 & 168 & 195 & 241 & 274 \\
$5-8^{z}$ & 168 & 195 & 241 & 274 \\
\hline
\end{tabular}

${ }^{2}$ Nutrient regime of treatments 5-8 was augmented by additional fertilization as outlined in Table 1

temperature prior to transplanting. Four additional transplant treatments were produced by augmenting the $150 \mathrm{~N}-60 \mathrm{P}-150 \mathrm{~K}\left(\mathrm{mg} \cdot \mathrm{L}^{-1}\right)$ regime of treatment 3 with either additional fertilizer application, modified handling practices, or both during the last 3 weeks before transplanting (Table 1). All fertilization was terminated on 30 Mar. Ten replicate trays of each transplant treatment were produced, the position of each randomly assigned in the green- house and lath house to minimize position effects. These eight treatments were transplanted into commercial fields near Winters and Newman on 7 and 11 Apr., respectively. Experimental design was a randomized complete block, with five 30-m-long singlebed replications per treatment per field. Individual plots contained $\approx 100$ plants. Transplanting was done mechanically, with a fertilizer application of $9 \mathrm{~kg} \cdot \mathrm{ha}^{-1} \mathrm{~N}$ and $11 \mathrm{~kg} \cdot \mathrm{ha}^{-1} \mathrm{P}$ banded just prior to transplanting at the Winters site. No fertilizer was applied at transplanting at the Newman site.

Initial plant height, shoot dry mass, and macronutrient content were determined for 60 plants of each treatment on 7 Apr. Macronutrient analysis was conducted as previously described. Percent stand loss was determined about a week after transplanting. Canopy development at Winters was quantified by a line quantum sensor (model 191; LI-COR, Lincoln, Nebr.). Readings taken beneath the plant canopy between $11 \mathrm{AM}$ and $1 \mathrm{PM}$ parallel to (30 Apr.) or perpendicular to (19 May) the plant row were compared to unshaded readings. Four (30 Apr.) or eight (19 May) individual readings per plot were taken. Percent light interception by the canopy was calculated:

$$
[1 \text { - (shaded / unshaded })]^{*} 100
$$

Harvesting and fruit quality assessment were done as described for 1999 trials. 


\section{Results}

1999. There was wide variation in initial transplant characteristics among treatments in each trial (Table 1). Root cell volume and plant height varied $>50 \%$, shoot $\mathrm{N}$ and $\mathrm{K}$ concentration by $>100 \%$. Shoot $P$ concentration was particularly variable, ranging from $1.3-11.7 \mathrm{~g} \cdot \mathrm{kg}^{-1}$. Some of the variation in macronutrient content resulted from pretransplanting treatment applied at UCD, but large differences in nutritional programs among commercial transplant growers were apparent by comparing the "normal hardening" treatments, which received no fertilization at UCD. Unfortunately, the commercial transplant producers would not divulge details of the greenhouse nutrient regimes employed, so no direct comparison could be made.

Frost occurred at Yolo 2d after transplanting, killing an average of $13 \%$ of transplants, but there was no significant difference among treatments in the percentage of plant loss. No treatment differences in plant loss were observed in either of the later trials, which did not experience temperature colder than $3{ }^{\circ} \mathrm{C}$ following transplanting; plant loss was $<5 \%$ in all treatments in both fields. Significant differences in relative growth rate (RGR) in the 3-4 weeks after transplanting were observed among treatments in all trials (Table 3). However, by midseason no visual differences in plant vigor remained apparent in any trial.

Total marketable fruit yield did not differ among treatments at Yolo or Knights Landing (Table 3). At Woodland, one treatment had significantly reduced yield. There were no treatment effects on crop maturity as measured by the percentage of green fruit $(<5 \%$ in all treatments in all trials) or juice color. Fruit SS, which ranged from 6.1 to 6.5 at Yolo and 5.2 to 5.5 at both Woodland and Knights Landing, was not affected by transplant treatment.

To further examine the relationship between transplant characteristics and field performance across trials, RGR and total fruit yield of each treatment at each site were scaled to their respective field means and regressed against original transplant characteristics (Table 4). Early season RGR was negatively correlated with root cell volume, and initial plant height and dry weight, suggesting that smaller transplants may become established more quickly. However, those correlations were nonsignificant with respect to fruit yield. Shoot P concentration was positively correlated with both RGR and fruit yield, and it was on the basis of this relationship that $\mathrm{P}$ nutrition was specifically addressed in 2000 .

2000. The nutrient regimes imposed resulted in generally higher shoot $\mathrm{N}$ concentrations that in 1999, with a range of $\mathrm{P}$ concentrations similar to 1999 (Table 1). Plant loss averaged $1 \%$ and $6 \%$ at Winters and Newman, respectively, with no significant treatment differences. Plant canopy development at Winters $23 \mathrm{~d}$ after transplanting was clearly limited in the $0 \mathrm{P}$ transplant treatment (Table 5), but by 6 weeks post-transplanting no differences in plant canopy were found.

Table 3. Relative growth rate (RGR) following transplanting, and subsequent marketable tomato fruit yield, 1999 trials.

\begin{tabular}{|c|c|c|c|c|}
\hline $\begin{array}{l}\text { Treatment } \\
\text { no. }\end{array}$ & $\begin{array}{c}\text { Greenhouse } \\
\text { source }\end{array}$ & $\begin{array}{c}\text { Finishing treatment } \\
\text { applied }\end{array}$ & $\begin{array}{c}\text { Relative } \\
\text { rowth rate (day) }{ }^{\mathrm{z}}\end{array}$ & $\begin{array}{c}\text { Total fruit } \\
\text { yield }\left(\mathrm{Mg} \cdot \mathrm{ha}^{-1}\right)\end{array}$ \\
\hline \multicolumn{5}{|c|}{ Yolo } \\
\hline 1 & 1 & normal hardening & $0.097 \mathrm{bc}^{\mathrm{y}}$ & 100.4 \\
\hline 2 & 2 & normal hardening & $0.089 \mathrm{~d}$ & 97.9 \\
\hline 3 & 3 & normal hardening & $0.103 \mathrm{ab}$ & 97.7 \\
\hline 4 & 3 & fertilization with $10-22-0$ & $0.107 \mathrm{a}$ & 100.6 \\
\hline 5 & 2 & water stress, in lath house & $0.092 \mathrm{~cd}$ & 91.4 \\
\hline 6 & 1 & 2-d dark exposure & $0.102 \mathrm{ab}$ & 103.5 \\
\hline 7 & 2 & 2-d dark exposure & $0.094 \mathrm{~cd}$ & 97.0 \\
\hline 8 & 1 & water stress, in greenhouse & $0.098 \mathrm{bc}$ & 101.3 \\
\hline 9 & & field standard & $0.097 \mathrm{bc}$ & 103.1 \\
\hline \multicolumn{5}{|c|}{ Woodland } \\
\hline 1 & 2 & normal hardening & $0.132 \mathrm{ab}$ & $116.1 \mathrm{ab}$ \\
\hline 2 & 2 & fertilization with $10-22-0$ & $0.134 \mathrm{a}$ & $121.3 \mathrm{a}$ \\
\hline 3 & 2 & water stress, in greenhouse & $0.129 \mathrm{ab}$ & $121.3 \mathrm{a}$ \\
\hline 4 & 2 & 2-d dark exposure & $0.133 \mathrm{ab}$ & $117.7 \mathrm{ab}$ \\
\hline 5 & 4 & normal hardening & $0.109 \mathrm{~d}$ & $117.5 \mathrm{ab}$ \\
\hline 6 & 5 & normal hardening & $0.137 \mathrm{a}$ & $124.7 \mathrm{a}$ \\
\hline 7 & 4 & fertilization with $10-22-0$ & $0.115 \mathrm{~cd}$ & $122.6 \mathrm{a}$ \\
\hline 8 & 4 & lath house day, $10^{\circ} \mathrm{C}$ chamber at night & $0.118 \mathrm{~cd}$ & $110.0 \mathrm{~b}$ \\
\hline 9 & & field standard & $0.123 \mathrm{bc}$ & $118.1 \mathrm{ab}$ \\
\hline \multicolumn{5}{|c|}{ Knights Landing } \\
\hline 1 & 2 & normal hardening & $0.082 \mathrm{bc}$ & 79.0 \\
\hline 2 & 2 & 2-d dark exposure & $0.094 \mathrm{ab}$ & 76.3 \\
\hline 3 & 2 & fertilization with $10-22-0$ & $0.099 \mathrm{a}$ & 80.6 \\
\hline 4 & 2 & fertilization with $20-9-17$ & $0.095 \mathrm{ab}$ & 80.6 \\
\hline 5 & 4 & normal hardening & $0.071 \mathrm{c}$ & 76.7 \\
\hline 6 & 4 & 2-d dark exposure & $0.074 \mathrm{c}$ & 75.6 \\
\hline 7 & 6 & normal hardening & $0.106 \mathrm{a}$ & 83.0 \\
\hline 8 & 7 & normal hardening & $0.081 \mathrm{bc}$ & 81.2 \\
\hline 9 & & field standard & $0.102 \mathrm{a}$ & 79.4 \\
\hline
\end{tabular}

${ }^{2}$ RGR for the initial 3 (Woodland and Knights Landing) or 4 weeks (Yolo) following transplanting.

y Mean separation by Duncan's multiple range test, $P=0.05$.

The same trend was observed at Newman, but was not quantified.

Treatments did not differ in total fruit yield (which ranged from 57 to $65 \mathrm{Mg} \cdot \mathrm{ha}^{-1}$ at Winters and 75 to $85 \mathrm{Mg} \cdot \mathrm{ha}^{-1}$ at Newman), crop maturity (averaging 3\% to $6 \%$ green fruit), or fruit quality. Fruit SS ranged from 5.7 to 6.2 at Winters and 5.8 to 6.3 at Newman, while color at both sites ranged only from 22 to 25 (dimensionless units representing the reflectance ratio of green to red light).

To directly evaluate the effect of low $\mathrm{P}$ status, orthogonal comparison of treatment 1 (no weekly $\mathrm{P}$ application) with treatments 2-4 (which received $30-90 \mathrm{mg} \cdot \mathrm{L}^{-1} \mathrm{P}$ fertigated in the greenhouse) was performed. Of all fruit yield and quality variables evaluated, only the percentage of green fruit at Winters showed a significant effect of low P status, with treatment 1 averaging $6 \%$ green while treatments 2-4 collectively averaged $3 \%$.

\section{Discussion}

The relatively minor effects of transplant production and handling practices on subsequent field performance documented in this study contrast with previous reports of significant, season-long effects. Weston and Zandstra (1986) reported early yield increased linearly with increasing root cell volume from 4-40 $\mathrm{cm}^{3}$, with highest total yield from the largest cell volume. Within the limited range of cell volume that we evaluated (which
Table 4. Relationship of initial transplant characteristics to crop relative growth rate (RGR) and fruit yield, 1999.

\begin{tabular}{lcc}
\hline $\begin{array}{l}\text { Transplant } \\
\text { characteristic }\end{array}$ & $\begin{array}{c}\text { Correlation } \\
\text { with }(\mathrm{RGR})^{\mathrm{z}}\end{array}$ & $\begin{array}{c}\text { Correlation } \\
\text { with fruit yield }\end{array}$ \\
\hline Root cell volume & $-0.60^{*}$ & -0.17 \\
Plant dry weight & $-0.84^{*}$ & -0.21 \\
Plant height & $-0.45^{*}$ & -0.25 \\
Shoot N & 0.07 & -0.06 \\
Shoot P & $0.57^{*}$ & $0.62^{*}$ \\
Shoot K & 0.24 & 0.01 \\
\hline
\end{tabular}

${ }^{2}$ Correlation $(r)$ of initial transplant characteristics with relative fruit yield or RGR across all 1999 trials, defined as: treatment mean / mean of all treatments in that trial

*Significant at $P=0.05$.

encompassed the range currently deemed economically and horticulturally practical by the California industry), root cell volume was unrelated to crop productivity.

The apparent association of both earlyseason RGR and fruit yield with initial shoot $\mathrm{P}$ concentration in 1999 was not confirmed in 2000; a transient effect in canopy development and a small delay in crop maturity at one site were the only observed effects of the wide range of $\mathrm{P}$ regime employed ( $\mathrm{P}$ fertigation rates from $0-90 \mathrm{mg} \cdot \mathrm{L}^{-1}$ ). Melton and Dufault (1991) reported that $40 \mathrm{mg} \cdot \mathrm{L}^{-1} \mathrm{P}$ increased early and total yield over a $10 \mathrm{mg} \cdot \mathrm{L}^{-1}$ regime, while Garton and Widders (1990) found that pretransplant conditioning with $5 \mathrm{~mm} \mathrm{P}$ increased total yield compared to a $2 \mathrm{~mm} P$ 
Table 5. Effect of transplant treatment on plant canopy development following transplanting, 2000 Winters trial.

\begin{tabular}{lccc}
\hline & & \multicolumn{2}{c}{ Light interception of canopy (\%) } \\
\cline { 3 - 4 } Treatment & Finishing treatment applied & $30 \mathrm{Apr}$ & 19 May \\
\hline 1 & $0 \mathrm{P}$ & $49 \mathrm{ab}$ & 38 \\
2 & $30 \mathrm{P}$ & $46 \mathrm{ab}$ & 42 \\
3 & $60 \mathrm{P}$ & $44 \mathrm{ab}$ & 43 \\
4 & $90 \mathrm{P}$ & $44 \mathrm{ab}$ & 41 \\
5 & trt 3+10-22-0 & $39 \mathrm{bc}$ & 40 \\
6 & trt 3 + water stress, in greenhouse & $46 \mathrm{ab}$ & 43 \\
7 & trt 3+20-9-17, in greenhouse & $52 \mathrm{a}$ & 45 \\
\hline
\end{tabular}

${ }^{\text {zMean separation by Duncan's multiple range test, } P=0.05 ; 19 \text { May treatment means not }}$ significantly different.

regime. The numerous reports of significant effects of greenhouse $\mathrm{N}$ regime on subsequent field productivity (Garton and Widders, 1990; Masson et al., 1991; Melton and Dufault, 1991; Vavrina et al., 1998; Weston and Zandstra, 1986; Widders, 1989) were not supported by the present study, in which no Nrelated effects were observed.

These disparate results can be reconciled by considering several factors. With the exception of Garton and Widders (1990) all these studies were conducted on fresh market tomato, in which early fruit production was of prime interest; most of these studies found greater effects on early yield than on total yield. In processing tomato production the relative proportion of the crop that matures early is of no significance, as long as overall crop timing is not significantly delayed. Also, most of these studies were conducted in more northern climates, in which early season temperatures are cooler (more stressful), and growing seasons shorter, than in central California. The vast differences between the results of Vavrina et al. (1998), who found 30 $60 \mathrm{mg} \cdot \mathrm{L}^{-1} \mathrm{~N}$ to be sufficient for tomato transplants in Florida, and Masson et al. (1991), who recommended $300-400 \mathrm{mg} \cdot \mathrm{L}^{-1} \mathrm{~N}$ for tomato transplants in Canada, illustrated the impact of climate on appropriate greenhouse nutrient management practices. Lastly, in the present study, liquid $\mathrm{N}$ and $\mathrm{P}$ fertilizer solution was applied at or just prior to transplanting in all but one trial field (the standard commercial practice in California), perhaps partially negating the influence of pretransplant nutritional regime.

The structure of this study did not allow clear comparison of the various hardening techniques employed (low temperature exposure, withholding water or nutrients, etc.). Although all treatments included some degree of hardening, the nature and relative intensity of those treatments differed substantially, particularly in 1999. The water stress treatments were particularly severe (prolonged, repeated wilting), while those receiving additional fertilizer (and water) were hardened only by the relatively mild temperatures encountered in the lath house (mean daily minimum of $8{ }^{\circ} \mathrm{C}$ ). The general lack of treatment effects on the percentage of plant loss, crop maturity, and fruit yield and quality suggested that neither the degree of hardening, nor the technique employed, was important. Treatment 8 at Woodland was the only treatment shown to reduce yield, yet it differed from treatment 5 in that trial only in that it received longer exposure to moderately low temperature $\left(10{ }^{\circ} \mathrm{C}\right)$, a traditional method of hardening. We conclude that successful transplant hardening can be accomplished in a variety of ways.

Commercial transplant production is complicated by the unpredictability of weather, which impacts both the rate of transplant growth in the greenhouse and the ability to plant fields on a timely basis. Transplant producers must constantly adjust their management to speed up or slow down transplant development in response to changing weather, and they are periodically required to hold field-ready plants for extended periods. It is impractical to follow a rigid set of production practices. This study showed that transplant producers have substantial flexibility in transplant management. We conclude that, for processing tomato production under Califor- nia conditions, widely disparate transplant production practices within the range tested here had little or no practical differential impact on subsequent field performance.

\section{Literature Cited}

Ciardi, J.A., C.S. Vavrina, and M.D. Orzolek, 1998. Evaluation of tomato transplant production methods for improving establishment rates. HortScience 33:229-232.

Garton, R.W. and I.E. Widders. 1990. Nitrogen and phosphorus preconditioning of small-plug seedlings influence processing tomato productivity. HortScience 25:655-657.

Hunt, R. 1990. Basic growth analysis. Unwin Hyman Ltd., London.

Kemble, J.M., J.M. Davis, R.G. Gardner, and D.C. Sanders. 1994. Root cell volume affects growth of compact-growth-habit tomato transplants. HortScience 29:261-262.

Leskovar, D.I., D.J. Cantliffe, and P.J. Stoffella. 1991. Growth and yield of tomato plants in response to age of transplants. J. Amer. Soc. Hort. Sci. 116:416-420.

Marr, C.W. and M. Jirak. 1990. Holding tomato transplants in plug trays. HortScience 25:173-176.

Masson, J., N. Tremblay, and A. Gosselin. 1991. Effects of nitrogen fertilization and HSP supplementary lighting on vegetable transplant production. II. Yield. J. Amer. Soc. Hort. Sci. 116:599602 .

Melton, R.R. and R.J. Dufault. 1991. Tomato seedling growth, earliness, yield, and quality following pretransplant nutritional conditioning and low temperatures. J. Amer. Soc. Hort. Sci. 116:421-425.

Sah, R.N. and R.O. Miller. 1992. Spontaneous reaction for acid dissolution of biological tissue in closed vessels. Anal. Chem. 64:230-233.

Sweeney, R.A. 1989. Generic combustion method for determination of crude protein in feeds: Collaborative study. J. Assn. Off. Anal. Chem. 72:770-774.

Vavrina, C.S., G.J.Hochmuth, J.A. Cornell, and S.M. Olson. 1998. Nitrogen fertilization of Floridagrown tomato transplants: Seasonal variation in greenhouse and field performance. HortScience 33:251-254.

Weston, L.A. and B.H. Zandstra. 1986. Effect of root container size and location of production on growth and yield of tomato transplants. J. Amer. Soc. Hort. Sci. 111:498-501.

Weston, L.A. and B.H. Zandstra. 1989. Transplant age and $\mathrm{N}$ and $\mathrm{P}$ nutrition effects on growth and yield of tomato. HortScience 24:88-90.

Widders, I.E. 1989. Pretransplant treatments of N and $\mathrm{P}$ influence growth and elemental accumulation in tomato seedlings. J. Amer. Soc. Hort. Sci. 114:416-420. 